deterioration in lung function, which has been described after nebulised asthma treatment in infancy, did not occur. ${ }^{3+}$

Ipratropium bromide acts on the nose by decreasing secretions but has not been shown to alter resistance in the nasal airway. As two infants with complete nasal blockage showed a $20 \%$ improvement in specific conductance we assume that the improvement seen after ipratropium bromide was due to bronchodilatation.

A Nebuhaler has been shown to be effective in giving inhaled budesonide to young children. We used this delivery system to give budesonide and $\beta_{2}$ agonists to asthmatic children aged under 2 and obtained dramatic improvement in many cases (unpublished results).

Though this method of delivery does not replace nebulisers in severe attacks of asthma in young children, it may enable many children without access to a nebuliser to be treated successfully at home. Handicapped patients who cannot use other inhalation devices may also benefit.

1 Hodges IGC, Groggins RC, Milner AD), Stokes GM. Bronchodilator effects of inhaled ipratropium bromide in wheezy toddlers. Arch Dis Child 1981;56: 729-32.

2 Radford M. Measurement of airway resistance and thoracic gas volume in infancy. Arch Dis Child 1974:49:611-5.

3 O'Callaghan C. Milner AD, Swarbrick A. Paradoxical deterioration in lung function after nebulised salbutamol in wheezy infants. Lancet 1986;ii: 1 124-5.

+ O'Callaghan C, Milner AD, Swarbrick A. Deterioration in lung function following nebulised ipratropium bromide in infancy followed by variable airways protection [A Shstract]. Eur Resp $\mathcal{F}$ in press.

5 Gleeson JGiA, Price JF. Controlled trial of budesonide given by the Nebuhaler in preschool children with asthma. $\mathrm{Br}$.Med $\mathcal{F}$ 1988;297:163-6.

Accepted 23 September 1988

\section{Profound hypotension after atenolol in severe hypertension}

\section{Mona Kholeif, Christopher Isles}

MRC Blood Pressure Unit, Western Infirmary, Glasgow G11 6NT Mona Kholeif, MRCP, registrar

Department of Medicine, Dumfries and Galloway Royal Infirmary, Dumfries DG1 4AP

Christopher Isles, MRCP, consultant

Correspondence to: Dr Kholeif.

BrMed f 1989;298:161-2 patients should be treated with one or two oral drugs. ${ }^{2}$ reduction in blood pressure.

\section{Case reports}

Because precipitous falls in blood pressure in patients with severe hypertension may cause ischaemic damage to vital organs ${ }^{1}$ reports have suggested that parenteral treatment should be avoided where possible and Such advice, however, does not always guarantee safe

Case 1-A 27 year old woman, previously untreated, complained of thirst, polyuria, and weight loss within eight weeks of taking a low oestrogen contraceptive pill (Loestrin 20). Her blood pressure was 192/142 mm Hg, and she had bilateral retinal haemorrhages, exudates, and papilloedema, confirming malignant hypertension. She was hyponatraemic $(128 \mathrm{mmol} / \mathrm{l})$ and hypokalaemic $(2.8 \mathrm{mmol} / \mathrm{l})$ but had normal renal function (serum creatinine concentration $102 \mu \mathrm{mol} / \mathrm{l}$ ). After she took $100 \mathrm{mg}$ atenolol her blood pressure fell considerably, reaching its lowest point, $72 / 40 \mathrm{~mm} \mathrm{Hg}$, at 18 hours (figure). Her serum creatinine concentration rose transiently to $138 \mu \mathrm{mol} / \mathrm{l}$, but there was no other evidence of ischaemia in other organs. Although her blood pressure was restored after infusion of 1 litre physiological saline, she did not require antihypertensive treatment for three days. Her renin activity and plasma concentrations of angiotensin II and aldosterone before treatment were shown subsequently to have been raised considerably at 2871 (normal range 9-50 mU/l), 1099 (5-35) pmol/l, and $4900(<500) \mathrm{pmol} / \mathrm{l}$ respectively. Renal arteriography gave normal results. Her blood pressure was subsequently controlled adequately at $130 / 90 \mathrm{~mm} \mathrm{Hg}$ with atenolol $100 \mathrm{mg}$ and chlorthalidone $25 \mathrm{mg}$ daily.

Case 2-A 51 year old woman, previously untreated, gave a three month history of gradually deteriorating vision and was found to be hypertensive with blood pressure $266 / 152 \mathrm{~mm} \mathrm{Hg}$. She had bilateral retinal haemorrhages, exudates, and papilloedema. Her serum sodium concentration was in the low normal range $(137 \mu \mathrm{mol} / \mathrm{l})$, she was hypokalaemic $(2.7 \mathrm{mmol} / \mathrm{l})$, and her renal function was moderately impaired (serum creatinine concentration $178 \mu \mathrm{mol} / \mathrm{l}$ ). She was treated with atenolol $50 \mathrm{mg}$ orally. Her blood pressure fell to $150 / 90 \mathrm{~mm} \mathrm{Hg} 10$ hours after the first dose and to $70 / 48 \mathrm{~mm} \mathrm{Hg} 14$ hours after the second dose (figure); her serum creatinine concentration rose transiently to $245 \mu \mathrm{mol} / \mathrm{l}$. Despite infusion of $500 \mathrm{ml}$ physiological saline her blood pressure remained low until dobutamine and dopamine were given, and further antihypertensive treatment was not required for 36 hours. Her renin activity and plasma concentrations of angiotensin II and aldosterone before treatment were shown subsequently to have been abnormally high at $687 \mathrm{mU} / \mathrm{l}, 191 \mathrm{pmol} / \mathrm{l}$, and $616 \mathrm{pmol} / \mathrm{l}$ respectively. Renal arteriography showed atheromatous occlusion of the right renal artery. Her blood pressure was controlled at $180 / 94 \mathrm{~mm} \mathrm{Hg}$ with enalapril $10 \mathrm{mg}$ daily.
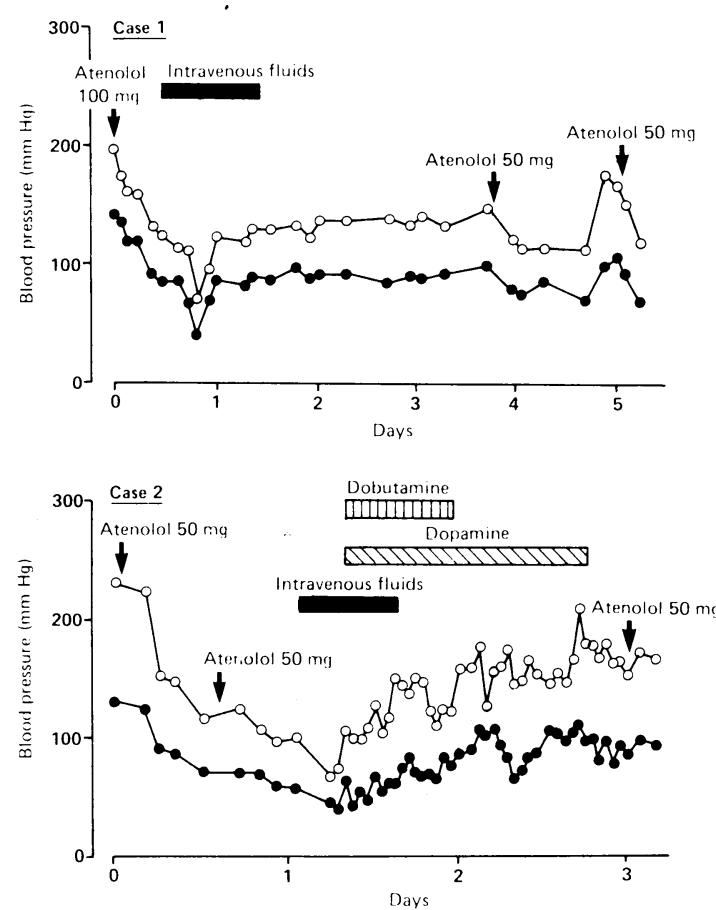

Blood pressure in two previously untreated patients with malignant hypertension taking atenolol. $\mathrm{O}=$ Systolic pressure; $\bullet=$ diastolic pressure

\section{Comment}

Increased plasma renin activity is a common, although not invariable, finding in malignant hypertension ${ }^{4}$ and occurs particularly in unilateral renal artery disease. Some hypertensive patients with extremely high renin activities develop hyponatraemia and hypokalaemia, often with thirst, polyuria, and weight loss, and are then said to have the hyponatraemic hypertensive syndrome. ${ }^{5}$ A likely explanation for this is that there is a positive feedback loop in which a high angiotensin II concentration raises 
arterial pressure, causing natriuresis, which leads to depletion of sodium and further raises the angiotensin II concentration. ${ }^{5}$ Given that the blood pressure of patients with the hyponatraemic hypertensive syndrome is renin dependent, our patients' pronounced hypotensive response to atenolol is not surprising.

The correct management of patients with this syndrome is unclear. It is not known whether blood pressure falls precipitously in all patients who take $\beta$ blockers or how far the risk of hypotension extends to those who take other classes of drugs. Bethanidine and captopril have been reported as causing serious hypotension, ${ }^{15}$ and we recommend that they be avoided as initial treatment.

We conclude that patients with malignant hypertension and hypokalaemia or hyponatraemia should be treated with low doses of $\beta$ blockers that can be raised according to the response of the blood pressure. Any precipitous fall in blood pressure can be reversed by a prompt infusion of saline, although temporary inotropic support may also be required.

1 Graham DI. Ischaemic brain damage of cerebral perfusion type after treatment of severe hypertension. Br.Med F 1979;iv: 739

2 Ledingham JGG. Management of hypertensive crises. Hypertension 1983;5 suppl III):114-9.

3 Isles $\mathrm{CG}$, Johnson AOC, Milne FJ. Slow response nifedipine and atenolol as initial treatment in blacks with malignant hypertension. $\mathrm{Br} f \mathrm{Clin}$ Pharmacol 1986;21:377-83.

4 Brown JJ, Davies DL, Lever AF, Robertson JIS. Plasma renin concentration in human hypertension. I. Relation between renin, sodium and potassium. BrMed f 1965;ii:144-8.

5 Atkinson AB, Brown JJ, Davies DL, et al. Hyponatraemic hypertensive syndrome with renal artery occlusion corrected by captopril. Lancet 1979;ii: $606-9$

(Accepted 5 October 1988)

\title{
Immune response of infants and preschool children to typhoid vaccine given intradermally or subcutaneously
}

\author{
V Mohandas, Thomas Cherian, G Sridharan, \\ Eric A F Simoes, S M Pereira, T Jacob John
}

\section{Christian Medical College and Hospital, Vellore, Tamilnadu 632 004, India $\mathrm{V}$ Mohandas, $\mathrm{MD}$, lecturer in child health \\ Thomas Cherian, MD, lecturer in child health \\ $\mathrm{G}$ Sridharan, PHD, lecturer in microbiology \\ Eric A F Simoes, MD, lecturer in child health \\ S M Pereira, FRCP, professor of child health \\ T Jacob John, FRCP, professor of microbiology and virology}

\section{Correspondence to:}

Professor John.

BrMed J 1989;298: 162-3
In developing countries typhoid fever is common not only in adults and children of school age but also in infants and preschool children, in whom the rate of complications and the case fatality rate may be as high as in older children. ${ }^{1}$ Children should therefore be immunised against typhoid fever as early as possible. The immunogenic and protective efficacies of the currently available heat inactivated typhoid vaccine have been investigated only in schoolchildren and adults. ${ }^{2+}$ We therefore measured its immunogenicity in infants and preschool children.

\section{Subjects, methods, and results}

From August 1985 to August 1986 infants (aged 6-11 months) and preschool children (aged 12-59 months) who had not been immunised against typhoid fever were recruited after parental consent had been obtained. The vaccine (King Institute, Madras) contained $500 \times 10^{6}$ heat killed Salmonella typhi, $250 \times 10^{6}$ heat killed $S$ paratyphi A, and $0.5 \%$ phenol in $0.5 \mathrm{ml}$. Subjects recruited in alternate weeks were vaccinated subcutaneously, and the others were

Rates of seroconversion and geometric mean titres of antibody to $S$ typhi $O$ and $H$ in infants and prechool children after typhoid vaccination

\begin{tabular}{|c|c|c|c|c|c|}
\hline \multirow[b]{2}{*}{$\begin{array}{c}\text { Age } \\
\text { (months) }\end{array}$} & \multirow[b]{2}{*}{$\begin{array}{l}\text { No of } \\
\text { children }\end{array}$} & \multicolumn{2}{|c|}{ Antibody to $S$ typhi $\mathrm{O}$} & \multicolumn{2}{|c|}{ Antibody to $S$ typhi $\mathrm{H}$} \\
\hline & & $\begin{array}{l}\text { No who developed } \\
\text { antibody/No } \\
\text { initially negative }(\%)\end{array}$ & $\begin{array}{c}\text { Geometric } \\
\text { mean } \\
\text { titre }\end{array}$ & $\begin{array}{l}\text { No who developed } \\
\text { antibody/No } \\
\text { initially negative }(\%)\end{array}$ & $\begin{array}{c}\text { Geometric } \\
\text { mean } \\
\text { titre }\end{array}$ \\
\hline \multicolumn{6}{|c|}{ Subcutaneous route } \\
\hline $\begin{array}{l}6- \\
12- \\
24-59\end{array}$ & $\begin{array}{l}52 \\
23 \\
20\end{array}$ & $\begin{array}{rr}40 / 51 & (78) \\
13 / 14 & (93) \\
7 / 10 & (70)\end{array}$ & $\begin{array}{l}80 \cdot 0 \\
84 \cdot 4 \\
65 \cdot 6\end{array}$ & $\begin{array}{l}52 / 52 \\
22 / 23 \quad(100) \\
19 / 19(100)\end{array}$ & $\begin{array}{l}265 \cdot 5 \\
411 \cdot 7 \\
222 \cdot 0\end{array}$ \\
\hline Total & 95 & $60 / 75 \quad(80)$ & $79 \cdot 1$ & $93 / 94 \quad(99)$ & $284 \cdot 0$ \\
\hline \multicolumn{6}{|c|}{ Intradermal route } \\
\hline $\begin{array}{l}6- \\
12- \\
24-59\end{array}$ & $\begin{array}{l}71 \\
20 \\
20\end{array}$ & $\begin{array}{ll}47 / 68 & (69) \\
13 / 20 & (65) \\
10 / 12 & (83)\end{array}$ & $\begin{array}{l}57 \cdot 8 \\
84 \cdot 3 \\
85 \cdot 7\end{array}$ & $\begin{array}{lr}69 / 71 & (97) \\
19 / 19 & (100) \\
18 / 19 & (95)\end{array}$ & $\begin{array}{l}251 \cdot 2 \\
257 \cdot 0 \\
201 \cdot 6\end{array}$ \\
\hline Total & 111 & $70 / 100(70)$ & $65 \cdot 6$ & $106 / 109$ & $244 \cdot 7$ \\
\hline
\end{tabular}

vaccinated intradermally. Subcutaneous vaccination $(0.5 \mathrm{ml})$ was given in the thigh, and intradermal vaccination $(0.1 \mathrm{ml})$ was given in the volar surface of the forearm. The second dose was given four weeks later by the same route. Blood was collected before the first vaccination and four weeks after the second. The serum was separated, diluted $1 / 5$ in isotonic saline, and stored at $-20^{\circ} \mathrm{C}$ until tested.

Serum samples were tested in dilutions of $1 / 20$ to $1 / 1280$ for the presence and titre of antibodies to $S$ typhi $\mathrm{O}$ and $\mathrm{H}$ antigens by tube agglutination with commercial antigens (Span Diagnostics, Bombay) and appropriate controls. 5 Subjects whose samples at a $1 / 20$ dilution did not contain antibody were considered to be negative for the antibody. If samples obtained from these children after vaccination contained antibody then seroconversion was considered to have occurred. The $\chi^{2}$ test was used to compare rates of seroconversion and the two tailed Student's $t$ test to compare the geometric mean titres of antibody.

Among the 363 subjects recruited into the study 289 returned for the second dose and 206 to give a blood sample after immunisation at the stipulated intervals; these 206 comprised 123 infants and 83 preschool children. The table shows the results. Of subjects who were initially negative for the antibody 60 of the 75 vaccinated subcutaneously and 70 of the 100 vaccinated intradermally developed antibodies to $\mathrm{O}$ antigen. This difference was not significant $\left(\chi^{2}=1 \cdot 75, p=0 \cdot 18\right)$. The proportions of subjects who became positive for antibody to $\mathrm{H}$ antigen were also not significantly different between the two groups $\left(\chi^{2}=0.12, p=0.72\right)$. In both vaccination groups, however, the proportion who became positive for antibody to $\mathrm{H}$ antigen was significantly higher than the proportion who became positive for $\mathrm{O}$ antigen $\left(\chi^{2}>15\right.$, $\mathrm{p}<0.001)$. The proportion who became positive for antibody to $\mathrm{O}$ or $\mathrm{H}$ antigen among infants, 1 year olds, and 2-4 year olds by each route was not significantly different $(\mathrm{p}>0.05)$.

The geometric mean titres of antibodies to $\mathrm{H}$ antigen after intradermal or subcutaneous vaccination were significantly higher than those of antibodies to $O$ antigen $(p<0 \cdot 001)$. There was no difference between the titres of antibodies to $\mathrm{O}$ or $\mathrm{H}$ antigen in those vaccinated subcutaneously and intradermally $(p>0.05)$ or in the titres among infants, 1 year olds, and 2-4 year olds $(\mathrm{p}>0.05)$.

\section{Comment}

Overall the immune response of infants and preschool children to the heat inactivated typhoid vaccine given subcutaneously or intradermally 